\title{
Human exposure to mercury in artisanal small-scale gold mining areas of Kedougou region, Senegal, as a function of occupational activity and fish consumption
}

\author{
Birane Niane - Stéphane Guédron • Robert Moritz • \\ Claudia Cosio • Papa Malick Ngom • Naresh Deverajan • \\ Hans Rudolf Pfeifer • John Poté
}

Received: 24 July 2014 / Accepted: 24 November 2014 / Published online: 12 December 2014

(C) Springer-Verlag Berlin Heidelberg 2014

\begin{abstract}
We investigated mercury ( $\mathrm{Hg}$ ) exposure of food web and humans in the region of Kedougou, Senegal, where $\mathrm{Hg}$ is used for gold amalgamation in artisanal small-scale gold mining (ASGM). For this purpose, total mercury (THg) concentration was determined in eight fish species and two shellfish species from Gambia River and in human hair from 111 volunteers of different age and sex, living in urban locations (Kedougou and Samekouta) or in ASGM areas (Tinkoto and Bantako). THg concentrations in fish samples range from 0.03 to $0.51 \mathrm{mg} \mathrm{kg}^{-1}$ wet weight (ww) and 0.5 to $1.05 \mathrm{mg} \mathrm{kg}^{-1}$ ww for shellfish. THg concentrations in fish are below the WHO guideline of $0.5 \mathrm{mg} \mathrm{kg}^{-1} \mathrm{ww}$, whereas $100 \%$ of shellfish are above this safety guideline. In the entire set of fish and shellfish samples, we documented a decrease of THg concentrations with increasing selenium to mercury (Se:Hg) ratio suggesting a protection of Se against $\mathrm{Hg}$. However, local population consuming fish from the Gambia River in the two ASGM areas have higher THg concentrations (median= 1.45 and $1.5 \mathrm{mg} \mathrm{kg}^{-1}$ at Bantako and Tinkoto) in hair than those from others localities (median $=0.42$ and $0.32 \mathrm{mg} \mathrm{kg}^{-1}$
\end{abstract}

Responsible editor: Philippe Garrigues

B. Niane $(\varangle) \cdot$ R. Moritz $\cdot$ C. Cosio $\cdot$ N. Deverajan · J. Poté Earth and Environmental Sciences, University of Geneva, rue des Maraîchers 13, 1205 Geneva, Switzerland

e-mail: birane.niane@unige.ch

S. Guédron

Institut des Sciences de la Terre, Université Grenoble 1, IRD / UMR

5275, BP 53, 38041 Grenoble, France

P. M. Ngom

Département de Géologie, Université Cheikh Anta DIOP, Dakar, Senegal

H. R. Pfeifer

Institut des Dynamiques de la Surface Terrestre, Université de Lausanne, Geopolis, 3871 Lausanne, Switzerland at Kedougou town and Samekouta) who have diverse diets. At ASGM sites, about $30 \%$ of the local population present $\mathrm{Hg}$ concentrations in hair exceeding $1 \mathrm{mg} \mathrm{kg}^{-1}$, defined as the reference concentration of $\mathrm{Hg}$ in hair. We also evidence a higher exposure of women to $\mathrm{Hg}$ in the Tinkoto ASGM site due to the traditional distribution of daily tasks where women are more involved in the burning of amalgams. The discrepancy between the calculated moderate exposure through fish consumption and the high $\mathrm{Hg}$ concentrations measured in hair suggest that fish consumption is not the only source of $\mathrm{Hg}$ exposure and that further studies should focus on direct exposure to elemental $\mathrm{Hg}$ of population living at ASGM sites.

Keywords Artisanal gold mining $\cdot$ Mercury .

Methylmercury $\cdot$ Selenium $\cdot$ Fish $\cdot$ Human health risk

\section{Introduction}

Mercury ( $\mathrm{Hg})$, especially under its organometallic form (methylmercury-MeHg), constitutes one of the main toxic metals in the aquatic environments due to its ability to biomagnify in food chains (Chen et al. 2005). Humans are mainly exposed to organic $\mathrm{Hg}$ through consumption of aquatic food (Zahir et al. 2005), while exposure to inorganic and/or elemental mercury occurs mostly through the inhalation of gaseous elemental Hg (Agency for Toxic Substances and Disease Registry (ATSDR) 1999). In artisanal small-scale gold mining (ASGM) sites, miners who directly handle $\mathrm{Hg}$ and burn amalgam, as well as persons living close to mining activity areas are exposed to inorganic Hg. Exposure to both forms of $\mathrm{Hg}$ has been linked with $\mathrm{Hg}$ neurotoxicity and other adverse health effects (Lebel et al. 1998).

Generally, total $\mathrm{Hg}$ content in blood, urine and hair is used to evaluate the human exposure to this toxic element in 
different environments. Compared to that in blood and urine, total mercury (THg) content in hair is widely used as a bioindicator of Hg contamination (Airey 1983; Matsubara 1985; Sakamoto et al. 2002) because of its non-invasive sampling, and since it can readily be obtained and stored. According to Johnson (2004), Hg contents in hair can generally be related to fish consumption. To determine the safe level of $\mathrm{Hg}$ exposure, the US Environmental Protection Agency (United States Environmental Protection Agency 1997) proposed a reference concentration of $1 \mathrm{mg} \mathrm{kg}^{-1}$ dry weight (dw) in hair corresponding to a reference dose for the methylmercury of $0.1 \mu \mathrm{g} \mathrm{kg}^{-1}$ body weight (bw) per day. Later on, Grandjean et al. $(1997,1999)$ showed that women with Hg levels below $10 \mathrm{mg} \mathrm{Kg}^{-1} \mathrm{dw}$ in hair can give birth to children with $\mathrm{Hg}$ related neuropsychological dysfunctions.

Recent studies have documented the antagonistic effect of selenium (Se) against the toxicity of mercury in aquatic organisms (Belzile et al. 2006; Chen et al. 2001). Belzile et al. (2006) suggested that Se plays an important role in limiting the whole-body assimilation of $\mathrm{Hg}$ at lower levels of $\mathrm{Hg}$ in the aquatic food chain. Peterson et al. (2009) suggested that the Se protective mechanism is related to the formation of highly stable organic MeHg-selenocysteine (MeHg-SeCys), which forms in the brain and nervous systems of Hg-stressed organisms, removing $\mathrm{Hg}$ from the biologically unavailable. Alternatively, Khan and Wang (2009) concluded that $\mathrm{Hg}$ can be sequestered in Se-bearing environments by in vivo biomineralization of $\mathrm{HgSe}_{x} \mathrm{~S}_{1-x}(\mathrm{~s})$ involving selenite and glutathione, which is thought to be the ultimate metabolic product responsible for the $\mathrm{Hg}-\mathrm{Se}$ antagonism in biological systems. However, using the selenium to mercury $(\mathrm{Se}: \mathrm{Hg})$ molar ratio in risk assessment, risk management and risk communication at this time is still open to debate, and more information is needed about $\mathrm{Hg}$ and $\mathrm{Se}$ interaction, and on the relationship between this molar ratio and health outcomes.

In sub-Saharan African countries, the environmental and health effects of $\mathrm{Hg}$ pollution have been reported for artisanal small-scale gold mining (ASGM) by Campbell et al. (2005), Donkor et al. (2006), Ikingura et al. (2006) and Ouédraogo and Amyot (2013). In Senegal, particularly in the Kedougou region along the Gambia River (Fig. 1), the use of $\mathrm{Hg}$ in ASGM has been increasing in recent years. Handling of $\mathrm{Hg}$ is mainly done by women during the amalgamation stage of the ore dressing, while men are engaged in the physical gold mining activities (Niane et al. 2014). During this process, a large quantity of $\mathrm{Hg}$ is discarded into the soil and the river system of the surrounding environment. After about 10 years of abundant $\mathrm{Hg}$ use in ASGM activities, environmental impacts are already noticeable (Niane et al. 2014). Consequently, there are potential environmental and health impacts of these activities, which have to be evaluated. Despite its recent introduction in the Kedougou region, little information is available on $\mathrm{Hg}$ exposure and its potential health effects in the local population.

Our study aimed to provide new data for a region where ASGM activities involving $\mathrm{Hg}$ amalgamation are recent and poorly documented. For this purpose, we have assessed the current status of Hg pollution in the Gambia River ecosystem analysing fish and shellfish as well as the exposure of the local population to $\mathrm{Hg}$ via fish consumption. The assessment was based on the evaluation of the concentration of $\mathrm{Hg}$ in the food chain and human hair of inhabitants from different localities and various sampling sites from the Kedougou region, Eastern Senegal. We also report Se contents in fish samples and discuss its potential role in $\mathrm{Hg}$ detoxification.

\section{Material and methods}

Study area

The main resources of gold of Senegal are located in the Kedougou Kenieba inlier, which is interpreted as an accretion of north-easterly trending Birimian volcanic terrains. According to Lawrence et al. (2013), the Kedougou Kenieba inlier (KKI) represents the westernmost exposure of the Birimian Supergroup (2050-2200 Ma) of the West African Craton. This gold region stretches across much of West Africa, including Senegal, Mali, Burkina Faso and the Ivory Coast. According to Bassot (1997), the KKI is subdivided into the Mako Supergroup (granite-greenstone belt) and an eastern Diale-Dalema series (sedimentary basin) (Fig. 1). The Mako Supergroup hosts the Sabodala deposit, the only industrial mine of the region exploited by Teranga Gold operation (TGO in Fig. 1). Gold mineralization is controlled by two major geological structures, which are the main transcurrent shear zone and the Senegalo-Malian fault (respectively, MTZ and SNF in Fig. 1; Sylla and Ngom 1997). Alluvial gold and goldbearing quartz veins hosted by shear zones are the two types of gold mineralization in Kedougou. About 30,000 to 60,000 artisanal miners are involved in ASGM in different villages of the region of Kedougou (Programme d'Appui au Secteur Minier PASMI 2009). Two types of sites were selected for this study (Fig. 1): (1) sites devoid of any mining activity, including Kedougou town, where inhabitants have a varied diet, and Samekouta, where inhabitants have a monotonous diet and (2) ASGM sites at Tinkoto and Bantako, where people are eating fish caught from the Gambia River (Fig. 1). The more expensive, larger and piscivorous fish are typically prepared at home or eaten in a restaurant in the mining areas of Tinkoto and Bantako. Both villages have distinct social differences. Bantako village, which is located along the Gambia River, has a population which includes about three quarters of immigrants; by contrast, Tinkoto is a traditional village with a majority of locally rooted population. 


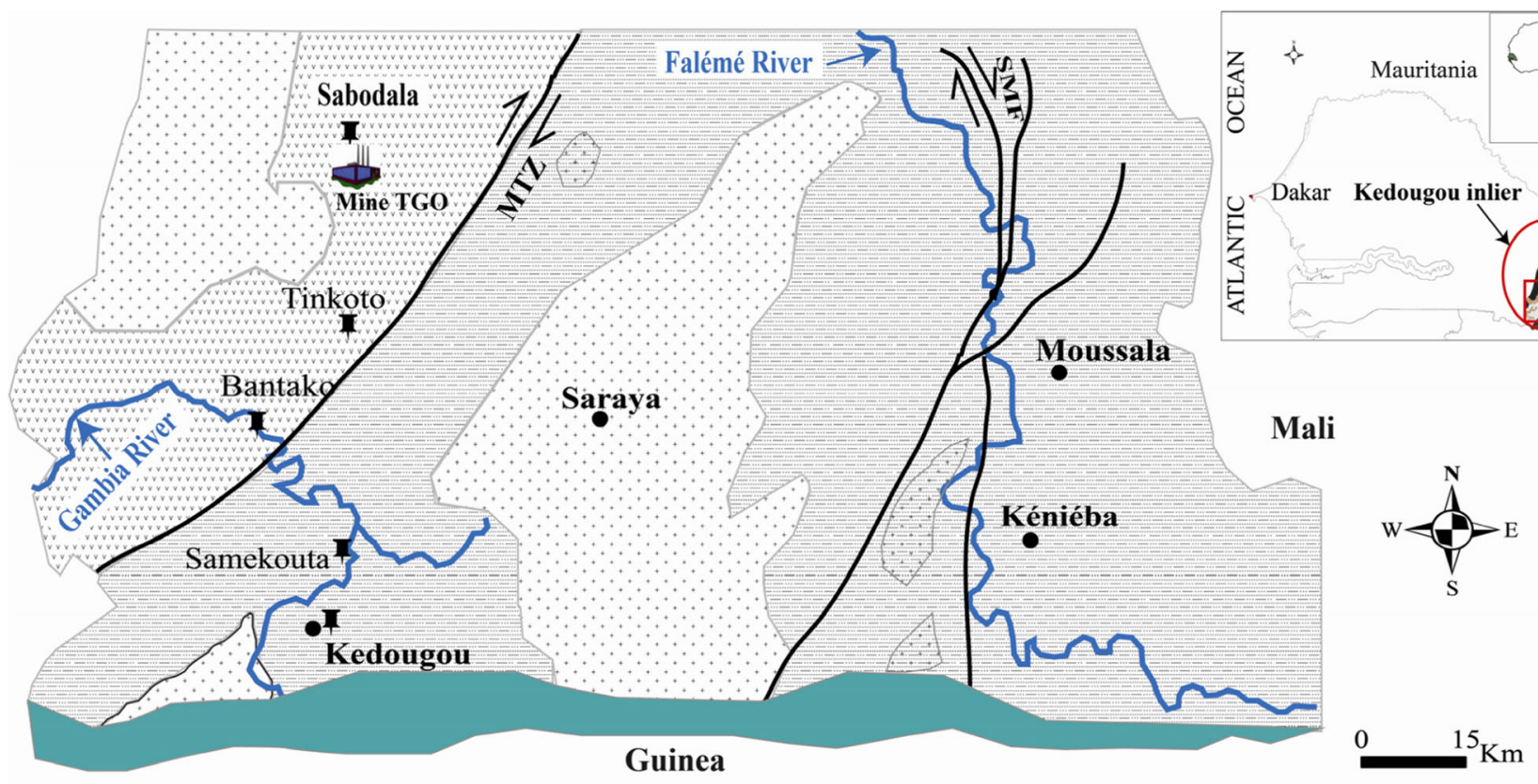

\section{Legend}

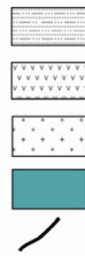

Volcano sedimentary rocks Dialé-Daléma supergroups

\section{Basics rocks (Mako supergroup)}

Saraya and Badon - Kakadian batholiths

Madina kouta basin

Major shear zones

Fig. 1 Geological map and localization of the main sampling sites modified after Niane et al. (2014)

\section{Sampling}

Fish samples $(n=32)$ were purchased from local fishermen along the Gambia River, and the shellfish $(n=7)$ were collected in Gambia River at Bantako (Table 1). The muscle tissue of fish samples were frozen on-site and stored at $-20{ }^{\circ} \mathrm{C}$ in clean polypropylene bottles until acid digestion at the University of Geneva, Switzerland. The digestion of fish samples and shellfish was performed according to the methods described by Rashed (2001) and Sivaperumal et al. (2007) with some modifications. Briefly, a portion of dorsal muscle tissue from each fish sample was freeze-dried and ground to obtain a fine powder. Then, approximately $1 \mathrm{~g}$ was digested in $10 \mathrm{ml}$ of a suprapur $\mathrm{HNO}_{3}-\mathrm{HClO}_{4}$ (3:1) mixture in Teflon bombs and heated overnight at $110{ }^{\circ} \mathrm{C}$. The digested samples were then cooled at room temperature and centrifuged.

One hundred and eleven human hair samples were collected from four local communities in Kedougou region between June 3 and 18, 2013, using clean stainless steel scissors (Table 2). A questionnaire including gender, age and frequency of fish consumption was completed by each volunteer who provided hair samples. Hair samples were washed twice with acetone and rinsed with Milli-Q water before analysis.

Analytical procedures

For both hair and fish samples, $\mathrm{Hg}$ analysis was carried out using atomic absorption spectrophotometry for mercury determination (Advanced Mercury Analyzer; AMA 254, Altec $\left.^{\circledR}\right)$ at the University of Geneva, Switzerland, as described by Bravo et al. (2010).

Digested fish samples were also analysed for Se by ICPMS at the University of Geneva, Switzerland (7700x series, Agilent $\left.{ }^{\circledR}\right)$. A collision/reaction cell (helium mode) and interference equations were utilized to correct spectral interferences. The certified reference material DORM-2 (fish muscle), DORM-3 (fish protein) and TORT-2 (lobster hepatopancreas) were used to verify the quality, the precision and the reliability of the results. The results are expressed in milligramme per kilogramme wet weight (ww) for fish muscle 
Table 1 Length (cm), weight $(\mathrm{g}), \mathrm{THg}(\mathrm{mg} / \mathrm{g} \mathrm{ww})$, diet habit and $\mathrm{Se}: \mathrm{Hg}$ molar ratio of each fish species

\begin{tabular}{|c|c|c|c|c|c|c|c|c|c|c|}
\hline \multirow[t]{2}{*}{$\begin{array}{l}\text { Sample } \\
\text { type }\end{array}$} & \multirow[t]{2}{*}{$\begin{array}{l}\text { Scientific name/ } \\
\text { diet habit }\end{array}$} & \multirow{2}{*}{$\begin{array}{l}\text { Number of } \\
\text { fish } \\
\text { sampled }\end{array}$} & \multirow[t]{2}{*}{$\begin{array}{l}\mathrm{L} \\
(\mathrm{cm})\end{array}$} & \multirow[t]{2}{*}{$\begin{array}{l}\text { Wt } \\
(\mathrm{g})\end{array}$} & \multicolumn{2}{|l|}{$\begin{array}{l}\mathrm{THg}(\mathrm{mg} \mathrm{kg} \\
-1 \text { ww) }\end{array}$} & \multicolumn{2}{|l|}{$\begin{array}{l}\text { Se (mg kg } \\
-1 \text { ww) }\end{array}$} & \multicolumn{2}{|c|}{$\begin{array}{l}\mathrm{Se}: \mathrm{Hg} \\
\text { (molar ratio) }\end{array}$} \\
\hline & & & & & Mean & Range & Mean & Range & Mean & Range \\
\hline \multirow[t]{9}{*}{ Fish } & Alestes dentex ${ }^{\mathrm{a}}$ & 1 & 18 & 25 & 0.16 & & 0.18 & & 2.82 & \\
\hline & Oreochromis niloticus $^{\mathrm{a}}$ & 1 & 33 & 750 & 0.04 & & 0.23 & & 14.06 & \\
\hline & $\begin{array}{l}\text { Sarotherodon } \\
\text { melanotheron }^{\mathrm{a}}\end{array}$ & 13 & $7-19.50$ & $10-200$ & $0.10 \pm 0.05$ & $0.03-0.22$ & $0.35 \pm 0.1$ & $0.28-0.48$ & 13.04 & $5.54-27.10$ \\
\hline & Hepsetus odoe & 3 & $22.5-32$ & $35-750$ & $0.39 \pm 0.13$ & $0.18-0.51$ & $0.5 \pm 0.03$ & $0.48-0.51$ & 3.98 & $2.50-6.70$ \\
\hline & Labeo parvus ${ }^{\mathrm{c}}$ & 3 & $13-13.50$ & $13-15$ & $0.06 \pm 0.03$ & $0.03-0.09$ & $0.34 \pm 0.11$ & $0.23-0.46$ & 18.90 & $9.80-34.70$ \\
\hline & Marcusenius senegalensis ${ }^{\mathrm{c}}$ & 2 & $27.5-46$ & $13-15$ & $0.07 \pm 0.004$ & $0.07-0.08$ & $0.45 \pm 0.15$ & $0.34-0.55$ & 16.56 & $11.9-21.2$ \\
\hline & Synondontis ocellifer ${ }^{\mathrm{c}}$ & 4 & $13-15$ & $10-15$ & $0.19 \pm 0.06$ & $0.14-0.26$ & $0.28 \pm 0.03$ & $0.22-0.40$ & 4.04 & $2.10-4.90$ \\
\hline & $\begin{array}{l}\text { Chrysichthys } \\
\text { nigrodigitatus }^{\mathrm{c}}\end{array}$ & 3 & $13-15$ & $19-21$ & $0.28 \pm 0.1$ & $0.21-0.37$ & $0.36 \pm 0.12$ & $0.26-0.43$ & 3.43 & $2.39-5.24$ \\
\hline & Schilbe intermedius ${ }^{\mathrm{b}}$ & 2 & $10-14$ & $200-400$ & $0.37 \pm 0.03$ & $0.35-0.39$ & $0.45 \pm 0.15$ & $0.46-0.45$ & 3.14 & $2.98-3.29$ \\
\hline \multirow[t]{2}{*}{ Shellfish } & Etheria elliptica & 2 & & & $0.60 \pm 0.07$ & $0.54-0.65$ & $0.5 \pm 0.19$ & $0.38-0.65$ & 2.16 & $1.76-2.60$ \\
\hline & Aspatharia senegalensis & 5 & & & $0.79 \pm 0.2$ & $0.63-1.05$ & $0.18 \pm 0.09$ & $0.04-0.35$ & 0.66 & $0.10-1.40$ \\
\hline
\end{tabular}

${ }^{\text {a }}$ Non-piscivorous

${ }^{\mathrm{b}}$ Piscivorous

${ }^{\mathrm{c}}$ Omnivorous

samples and in milligramme per kilogramme dry weight (dw) for hair samples.

Molar concentrations per fish were obtained by dividing the concentration of the total mercury by its molecular weight of 200.59, and the concentration of the total selenium by its molecular weight of 78.9. Mean Se:Hg molar ratios were calculated from the mean selenium and mean mercury concentrations in each fish species.
Statistical analysis

The Kolmogorov-Smirnov test was used to evaluate the normality of the data. The Kruskal-Wallis test was used for multiple sample comparison ( $H$ test). All the statistical tests were performed using Statistica (12.0) software, and a $p$ value of 0.05 was chosen to indicate the statistical significance.

Table 2 Concentration of $\mathrm{THg}\left(\mathrm{mg} \mathrm{kg}^{-1}\right)$ in the hair of studied volunteers

\begin{tabular}{|c|c|c|c|c|c|}
\hline & $\begin{array}{l}\text { All } \\
(n=111)\end{array}$ & $\begin{array}{l}\text { Kedougou } \\
(n=25)\end{array}$ & $\begin{array}{l}\text { Samekouta } \\
(n=38)\end{array}$ & $\begin{array}{l}\text { Tinkoto } \\
(n=20)\end{array}$ & $\begin{array}{l}\text { Bantako } \\
(n=28)\end{array}$ \\
\hline Median & 0.57 & 0.42 & 0.32 & 1.5 & 1.45 \\
\hline Max & 7.67 & 1.24 & 1.44 & 6.26 & 7.67 \\
\hline Min & 0.1 & 0.1 & 0.12 & 0.25 & 0.33 \\
\hline Geometric mean & 0.65 & 0.39 & 0.34 & 1.48 & 1.45 \\
\hline Arithmetic mean & 1.1 & 0.46 & 0.41 & 2.12 & 2.03 \\
\hline SD & 1.41 & 0.27 & 0.28 & 1.87 & 1.83 \\
\hline Male $(n)$ & 50 & 10 & 20 & 8 & 12 \\
\hline Age mean ${ }^{a}$ & & 36.6 & 14.9 & 28 & 19.7 \\
\hline Range & & $(3-60)$ & $(1-35)$ & $(6-51)$ & $(1-37)$ \\
\hline Female $(n)$ & 61 & 15 & 18 & 12 & 16 \\
\hline Age mean ${ }^{a}$ & & 21.8 & 21.2 & 29.9 & 15.4 \\
\hline Range & & $(2-45)$ & $(3-45)$ & $(1-56)$ & $(1-43)$ \\
\hline
\end{tabular}

$S D$ standard deviation

${ }^{\mathrm{a}}$ Years 


\section{Results}

$\mathrm{Hg}$ and Se concentrations in fish and shellfish

Table 1 and Fig. 2a show the mean THg (mg/kg ww) and the standard deviation (SD) in fish according to their diet habit, length and weight. The highest mean $\mathrm{THg}$ is found in shellfish tissues $\left(0.7 \pm 0.2 \mathrm{mg} \mathrm{kg}^{-1} \mathrm{ww}, n=7\right)$. Amongst fish species, the highest mean $\mathrm{THg}$ concentrations are found in piscivorous fish $\left(0.4 \pm 0.1 \mathrm{mg} \mathrm{kg}^{-1} \mathrm{ww}, n=5\right)$ and omnivorous fish $(0.3 \pm$ $\left.0.09 \mathrm{mg} \mathrm{kg}^{-1} \mathrm{ww}, n=8\right)$, being significantly higher than $\mathrm{THg}$ in non-piscivorous fish (including non-piscivorous, invertivorous and limnivorous) $\left(0.09 \pm 0.05 \mathrm{mg} \mathrm{kg}^{-1} \mathrm{ww}, n=\right.$ 19).

The range of mean Se concentrations (0.2 to $\left.0.5 \mathrm{mg} \mathrm{kg}^{-1} \mathrm{ww}\right)$ amongst fish species and shellfish is lower than that of $\mathrm{Hg}\left(0.04\right.$ to $\left.0.79 \mathrm{mg} \mathrm{kg}^{-1} \mathrm{ww}\right)$ and without significant differences between mean Se concentrations and diet habits (Table 1). The calculated Se:Hg molar ratios vary greatly amongst fish and shellfish species (0.6 to 18.9). For the fish species, Oreochromis niloticus, Sarotherodon melanotheron, Labeo parvus and Marcusenius senegalensis yielded the larger mean Se:Hg molar ratios between 13 and 19, whereas those of the other fish species remain around 3 to 4 (Table 1). Se:Hg ratios in shellfish are the lowest ones, ranging between 0.7 and 2.2 (Table 1, Fig. 2b). Figure 2c reveals that Se:Hg molar ratios and $\mathrm{THg}$ concentrations are inversely related, with the highest $\mathrm{Se}: \mathrm{Hg}$ ratios corresponding to the lowest THg contents.

\section{$\mathrm{THg}$ concentrations in hair}

The descriptive statistics of the THg concentration in hair for the entire group, including men and women, are given in Table 2. The mean $\mathrm{THg}$ concentrations in hair samples of volunteers are $1.1 \pm 1.4 \mathrm{mg} \mathrm{kg}^{-1}(0.1-7.7, n=111)$. In this study, we chose the $1 \mathrm{mg} \mathrm{Hg} \mathrm{kg}^{-1} \mathrm{dw}$ in hair as the threshold level according to the USA (US Environmental Protection Agency (1997)). Our study indicates that $29 \%$ of the sampled volunteers exceed this level.

Figure $3 \mathrm{a}$ shows that mean $\mathrm{THg}$ concentrations in hair samples is significantly higher $(H$ test, $p$ value $<0.001)$ for the communities living at the mining sites of Bantako $(2.1 \pm$ $\left.1.9 \mathrm{mg} \mathrm{kg}^{-1} \mathrm{dw}, n=20\right)$ and Tinkoto $\left(1.9 \pm 1.7 \mathrm{mg} \mathrm{kg}^{-1} \mathrm{dw}, n=\right.$ 28) compared to those from the non-mining sites at Kedougou City $\left(0.5 \pm 0.3 \mathrm{mg} \mathrm{kg}^{-1} \mathrm{dw}, n=25\right)$ and Samekouta $(0.4 \pm$ $\left.0.3 \mathrm{mg} \mathrm{kg}^{-1} n=38\right)$. $\mathrm{Hg}$ concentration in hair collected from women (mean $2.5 \mathrm{mg} \mathrm{kg}^{-1} \mathrm{dw}$, Table 2) is 2.3 times higher than that in hair from men (mean $1.1 \mathrm{mg} \mathrm{kg}^{-1} \mathrm{dw}$, Table 2) at Tinkoto (Fig. 3b). By contrast, there is no difference in $\mathrm{Hg}$ concentrations in hair between genders at the other sites (Fig. 3b).
Figure $3 \mathrm{c}$ shows that the median $\mathrm{Hg}$ concentration in hair for the group with the highest fish consumption per week in the ASGM sites (i.e. Bantako and Tinkoto, median= $2.4 \mathrm{mg} \mathrm{kg}^{-1} \mathrm{dw}$ ) is almost 6.4 times higher than the median value of the same group from the non-mining control sites (i.e. Kedougou and Samekouta, median $=0.38 \mathrm{mg} \mathrm{kg}^{-1} \mathrm{dw}$ ). Amongst hair samples collected from people living in ASGM sites (i.e. Bantako and Tinkoto), the group that rarely or never eats fish has a median $\mathrm{Hg}$ concentration in hair of $0.97 \mathrm{mg} \mathrm{kg}^{-1} \mathrm{dw}$, being 2.6 times higher than the median value of $0.39 \mathrm{mg} \mathrm{kg}^{-1} \mathrm{dw}$ of the same group from Kedougou and Samekouta (Fig. 3c). In the non-mining control sites (i.e. Kedougou and Samekouta), there is no difference between the groups consuming fish twice or more every week and the one consuming fish no more than once a week. In contrast, in the ASGM sites of Tinkoto and Bantako, there is a statistically significant difference $(H$ test, $p$ value $=0.003)$ of $\mathrm{Hg}$ concentration in hair between these two groups (Fig. 3c).

When considering the $\mathrm{Hg}$ concentration in the hair of children and women of childbearing potential (Fig. 3d), the mean $\mathrm{Hg}$ concentration in hair samples of women, children and women who have given birth to children is below the recommended threshold value of $1 \mathrm{mg} \mathrm{kg}^{-1} \mathrm{dw}$ at the control sites of Kedougou town and Samekouta. In contrast, in active ASGM sites at Bantako and Tinkoto, the mean $\mathrm{Hg}$ in the hair of these two groups is above the lowest threshold value defined by the US EPA (Fig. 3d). These two groups are considered by the World Health Organization (WHO) as groups at risk with respect to $\mathrm{Hg}$ exposure because they are particularly vulnerable and more sensitive to the adverse neurological effects of methylmercury. Some studies have shown that prenatal $\mathrm{MeHg}$ exposure can produce adverse neurological effects on children and risk of preterm delivery (Bose-O'Reilly et al. 2010; Grandjean et al. 1998; Murata et al. 2004; Xue et al. 2007). Maternal exposure to $\mathrm{MeHg}$ is a risk to the offspring because it passes readily through the placenta to the foetus (Bjornberg et al. 2005; Kajiwara et al. 1996).

\section{Discussion}

\section{Contamination of fish from Gambia River}

Piscivorous fishes (Hepsetus odoe, Schilbe intermedius) have mean $\mathrm{THg}$ concentrations of $0.38 \mathrm{mg} \mathrm{kg}^{-1}$ which are close but still below the WHO's safety consumption guideline of $0.5 \mathrm{mg} \mathrm{kg}^{-1}$ (World Health Organization 2004), and those of non-piscivorous fishes (Sarotherodon melanotheron, Synodontis ocellifer, L. parvus) are of $0.09 \mathrm{mg} \mathrm{kg}^{-1}$ which remain five times below the above-mentioned threshold value (Fig. 2a). These mean concentrations of 0.09 and 
Fig. 2 Box plots of the total mercury in fish (a) and $\mathrm{Se}: \mathrm{Hg}$ molar ratios in fish species (b). Dotted line represents $\mathrm{Se}: \mathrm{Hg}$ molar ratios 1:1. Se:Hg molar ratios versus $\mathrm{THg}$ in sampled fish and shellfish (c)
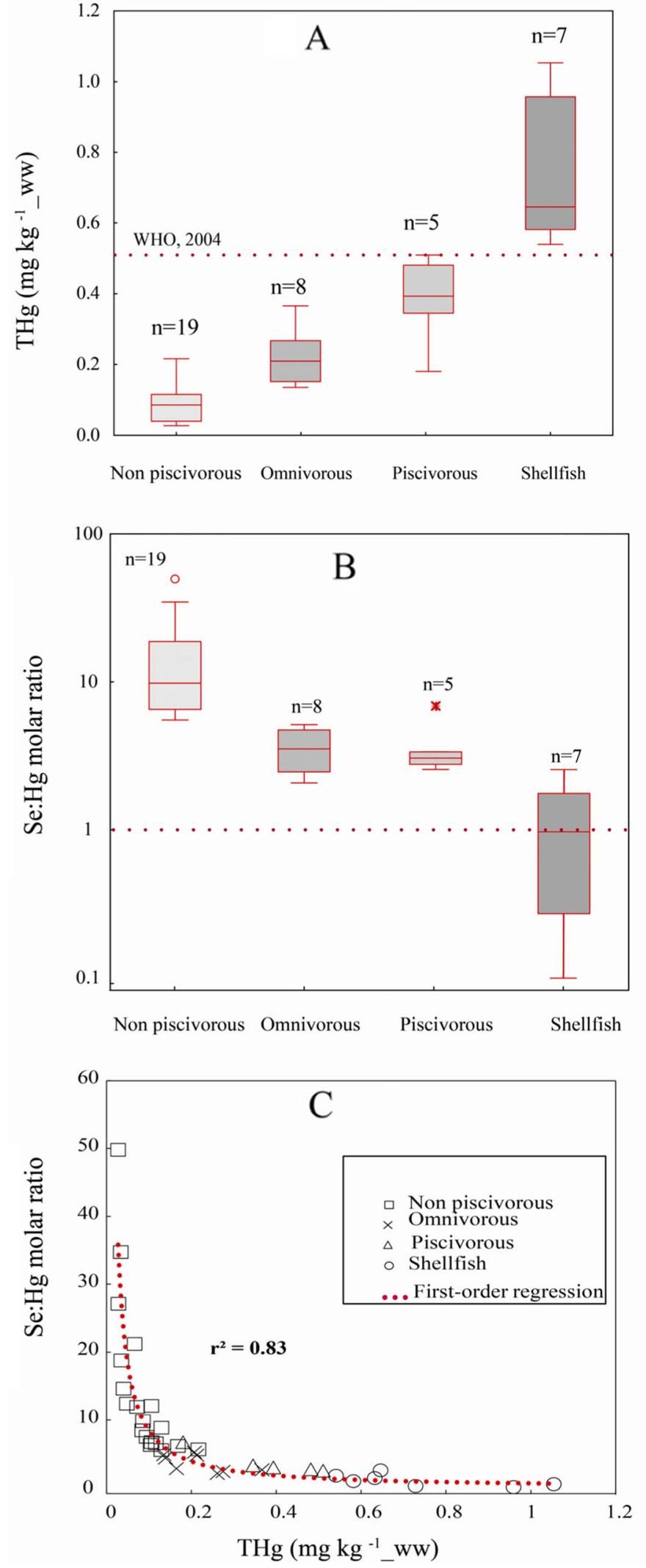

$0.38 \mathrm{mg} \mathrm{kg}^{-1}$ are higher than those reported for carnivorous fishes $\left(0.08 \pm 0.02 \mathrm{mg} \mathrm{kg}^{-1} \mathrm{ww}\right)$ from pristine areas (Guédron et al. 2014) but remain lower than concentrations in fish of 0.3 to $3.6 \mathrm{mg} \mathrm{kg}^{-1}$ reported in other regions, such as Ghana, 

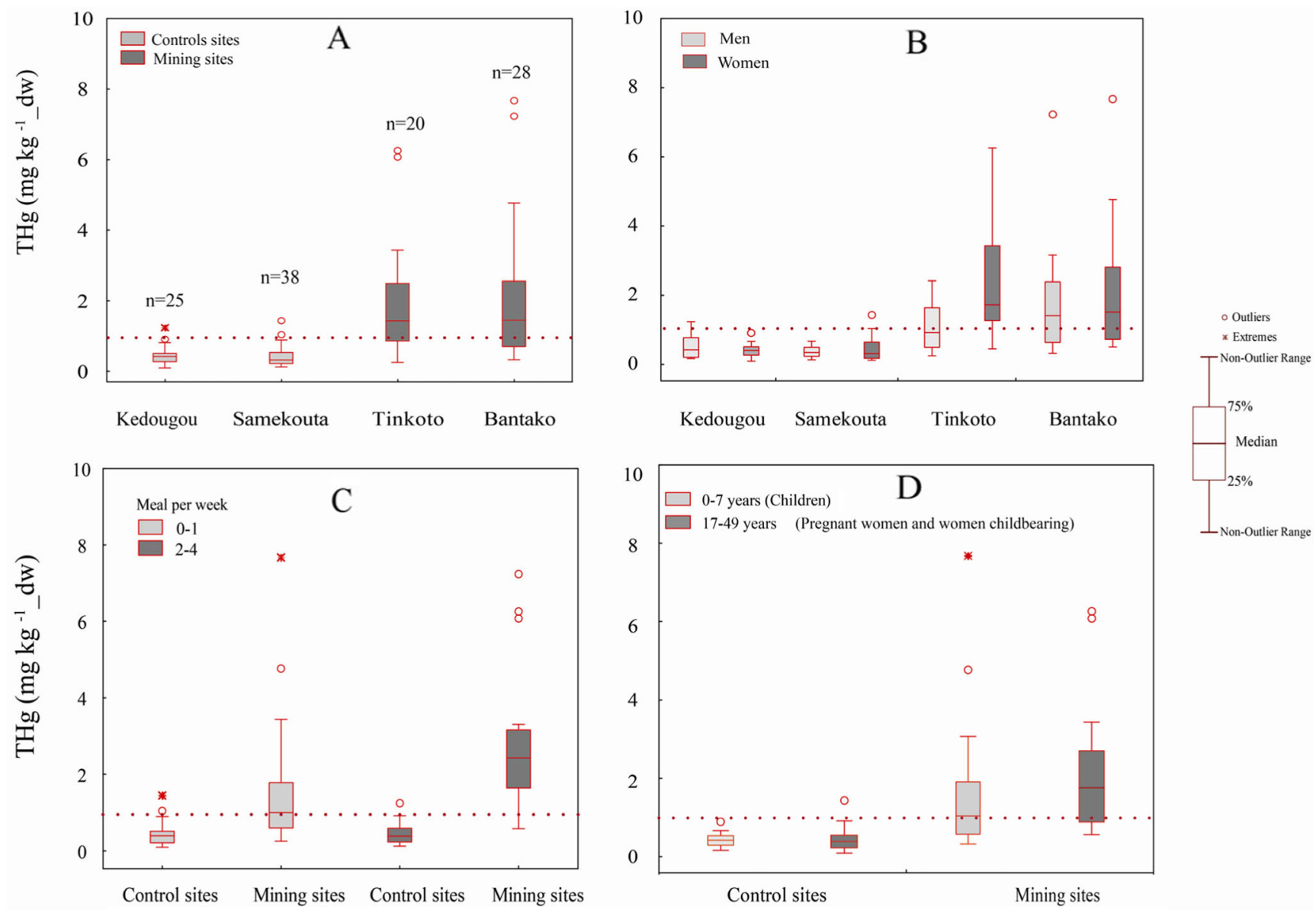

Fig. 3 Box plots of the concentration of total mercury in hair in relation to residence area (a) and to gender (b). Box plots of the total mercury in hair in relation to fish consumption (c) and to at-risk groups (d). Dotted line represents the US EPA threshold of $1 \mathrm{mg} \mathrm{kg}^{-1} \mathrm{dw}$

Tapajos river basin and Tunisia (Barbosa et al. 2001; Donkor et al. 2006; Dos Santos et al. 2000; Mezghani-Chaari et al. 2011; Kidd et al. 2004; Ouédraogo and Amyot 2013).

The increase of mean THg concentrations in fish from nonpiscivorous to omnivorous and to piscivorous species is in accordance with the common increase in $\mathrm{THg}$ concentrations along trophic chains reported for numerous aquatic ecosystems around the world (Kwaansa-Ansah et al. 2011; Ouédraogo and Amyot 2013). These relatively high THg concentrations in fish are related to the recent use of $\mathrm{Hg}$ amalgamation during ASGM activities in the region of Kedougou. Indeed, Bantako (Fig. 1), where shellfish is caught, is a site with highly Hg-contaminated sediments (average value $4.3 \mathrm{mg} \mathrm{kg}^{-1}$ ) along Gambia River (Niane et al. 2014). The high THg concentrations determined in shellfish (Fig. 2a) can be explained by the fact that such species live within bottom sediments and therefore are more exposed to Hg-contaminated sediments than pelagic species. According to Harris and Bodaly (1998) and Black et al. (2011), the higher growth rate of fish and the shorter life span of fish in the tropics or differences in the food web structure can explain the low mercury concentration in fish.
As for $\mathrm{Hg}$, Se concentration increases from nonpiscivorous to piscivorous fish according to their trophic level. The biomagnification of $\mathrm{Hg}$ and $\mathrm{Se}$ along the food web in Kedougou region is consistent with previous studies in tropical areas (Campbell et al. 2008; Kidd et al. 2003; Ouédraogo and Amyot 2013). The Se:Hg molar ratios of the nonpiscivorous fishes most frequently consumed by inhabitants and omnivorous and piscivorous fishes are above 1 (Table 1, Fig. 2b), meaning there is an excess of Se relative to $\mathrm{Hg}$. Considering all sampled fish and shellfish species, a significant relationship is found between THg concentrations and $\mathrm{Se}: \mathrm{Hg}$ molar ratios evidencing that higher $\mathrm{THg}$ concentrations are found for species which have the lowest Se:Hg molar ratios (Figs. 2b, c). This observation is in accordance with previous studies, which suggested that an excess of Se confers a protective advantage for fish (Burger and Gochfeld 2012) and that high Se:Hg molar ratios are favourable for Se neutralization of the $\mathrm{Hg}$ toxic effects in the upper trophic levels. Several studies have suggested that Se:Hg molar ratios above 1 protect against $\mathrm{Hg}$ toxicity (Ralston et al. 2006; Peterson et al. 2009; Ralston and Raymond 2010) because of the formation of insoluble $\mathrm{Se}-\mathrm{Hg}$ complexes, which sequester 
Hg from biological processes and neutralize its toxic effects (Belzile et al. 2009; Khan and Wang 2009; Peterson et al. 2009; Sørmo et al. 2011). However, the degree of Se excess necessary to counteract the toxic effect of $\mathrm{Hg}$ is still unclear, and recent studies showed that other contaminants may reduce the concentration of Se in water (Burger and Gochfeld. 2012; Gochfeld et al. 2012; Ouédraogo and Amyot 2013). Therefore, care should be taken before integrating $\mathrm{Se}: \mathrm{Hg}$ ratios in risk assessments about $\mathrm{Hg}$ toxicity.

\section{Fish consumption advisories}

According to Clarkson (2002) and Johnson (2004), consumption of contaminated freshwater fish is directly related to an increase in $\mathrm{Hg}$ concentrations in hair. We can assess the potential health risk by comparing the estimated dietary exposure to $\mathrm{MeHg}$ from fish and shellfish intake using the safety guideline levels recommended by the joint FAO/WHO Expert Committee on Food Additives (JECFA) such as the provisional tolerable weekly intake (PTWI) of MeHg of $1.6 \mu \mathrm{g} \mathrm{kg}^{-1}$ bw week $^{-1}$ (UNEP/WHO (2008); World Health Organization 2004).

The mean MeHg concentration in all fishes can be estimated based on a $0.8 \mathrm{MeHg} / \mathrm{THg}$ ratio (Bloom, 1992). This ratio is commonly used and validated by the $\mathrm{Hg}$ community since numerous publications evidenced percentages of $\mathrm{MeHg}$ in riverine and marine fish largely exceeding $80 \%$ of $\mathrm{THg}$ (e.g. Francesconi and Lenanton 1992; Grieb et al. 1990; Hammerschmidt et al. 1999; Mason et al. 2000; Orihel et al. 2007). Based on this ratio, the calculated mean of $\mathrm{MeHg}$ concentration are $0.07 \pm 0.04 \mathrm{mg} / \mathrm{kg}$ ww for non-piscivorous, $0.32 \pm 0.1 \mathrm{mg} / \mathrm{kg} \mathrm{ww}$ for piscivorous, $0.18 \pm 0.06 \mathrm{mg} / \mathrm{kg} \mathrm{ww}$ for omnivorous species and $0.6 \pm 0.14 \mathrm{mg} / \mathrm{kg}$ ww for shellfish (Table 3). Thus, a standard meal with $227 \mathrm{~g}$ of fish or shellfish (World Health Organization 2004) contains $15.9 \mu \mathrm{g} \mathrm{MeHg}$ if non-piscivorous fish is considered, $40.9 \mu \mathrm{g} \mathrm{MeHg}$ for omnivorous fish, $72.6 \mu \mathrm{g} \mathrm{MeHg}$ for piscivorous fish and $136.2 \mu \mathrm{g}$ $\mathrm{MeHg}$ for shellfish, with only the latter exceeding the PTWI of $112 \mu \mathrm{g} \mathrm{MeHg}$ for a 70-kg heavy person (World Health
Organization, 2004). The reported national average of weekly fish consumption by Senegalese people is stated as $430 \mathrm{~g} /$ week (Food and Agriculture Organization 2003). However, this national average of weekly fish consumption is not representative of distal places since it is based on the majority of the population living along the Atlantic coast and eating larger amounts of fish than the communities remote from main fishing locations, such as Kedougou. Therefore, we used the standard meal value for fish consumption rate of $227 \mathrm{~g} /$ week in Kedougou region which appears to be more realistic. Considering an adult man of $70 \mathrm{~kg}$ or an adult woman of $65 \mathrm{~kg}$, the provisional weekly intake (PWI) for a single fish meal per week ranges between 0.2 and $1.1 \mathrm{mg} \mathrm{kg}^{-1}$ body weight (bw) (Table 3) depending on the consumed fish species (i.e. nonpiscivorous to piscivorous) and reaches 1.9 to $2.1 \mathrm{mg} \mathrm{kg}^{-1}$ bw for a shellfish meal. Such values are below the World Health Organization (2004) safety guideline of $1.6 \mu \mathrm{g} \mathrm{kg}^{-1}$ for fish, whereas it exceeds this value for shellfish. However, when considering three to four fish meals per week, this guideline is easily exceeded.

Evaluation of human exposure to $\mathrm{Hg}$ and recommendations

Mercury concentrations measured in hair samples obtained from inhabitants of ASGM sites (Tinkoto and Bantako) (Fig. 3, Table 2) largely exceed the $1 \mathrm{mg} \mathrm{kg}^{-1}$ guideline recommended by the USA (United States Environmental Protection Agency (1997)). In these locations, inhabitants consume larger piscivorous fish caught in the Gambia River, which are more expensive, and are typically prepared at home or eaten in a restaurant. Because of the price of gold, it confers a higher income to the population of mining areas (Tinkoto and Bantako) than to the remaining parts of the region. In contrast, hair collected from people living outside of the gold mining areas at Samekouta and Kedougou City (Fig. 3a) have $\mathrm{Hg}$ concentrations far below the above guideline. These results reflect a lower exposure to $\mathrm{Hg}$ of people living outside of gold mining areas, who have a more diverse diet and who consume imported fish rather than local fish from Gambia

Table 3 Allowable fish consumption estimates based on average body weight of 65 and $70 \mathrm{~kg}$ for woman and man, respectively, and provisional weekly intake (PWI) based on $\mathrm{MeHg}$ concentration and mean weight of each fish species

\begin{tabular}{|c|c|c|c|c|c|c|c|}
\hline \multirow[t]{2}{*}{ Fish species } & \multirow[t]{2}{*}{ Number of samples } & \multirow{2}{*}{$\begin{array}{l}\text { Mean } \\
\text { weight (g) }\end{array}$} & \multirow{2}{*}{$\begin{array}{l}\text { Mean } \mathrm{MeHg} \\
\left(\mu g g^{-1} \text { ww }\right)\end{array}$} & \multicolumn{2}{|c|}{ Allowable fish consumption per week ( $\mathrm{g}$ ) } & \multicolumn{2}{|c|}{ PWI $\left(\mu \mathrm{gg}^{-1}\right)$} \\
\hline & & & & Man & Woman & Man & Woman \\
\hline Non-piscivorous & 19 & 73.94 & $0.07 \pm 0.04$ & 1600 & 1486 & 0.2 & 0.22 \\
\hline Piscivorous & 5 & 277 & $0.32 \pm 0.1$ & 350 & 325 & 0.91 & 0.98 \\
\hline Omnivorous & 8 & 16.25 & $0.18 \pm 0.06$ & 622 & 578 & 0.51 & 0.55 \\
\hline Shellfish & 7 & nd & $0.6 \pm 0.14$ & 187 & 173 & 1.71 & 1.85 \\
\hline
\end{tabular}

PWI values in italics above the provisional tolerable weekly intake (PTWI) (UNEP/WHO, 2008; World Health Organization, 2004) safety guideline of $1.6 \mu \mathrm{g} \mathrm{kg}^{-1}$

$n d$ no data 
River. In addition, at Samekouta, fishermen and inhabitants consume higher quantities of smaller non-piscivorous fishes (S. melanotheron) from Gambia River than other fish species. They prefer to sell the piscivorous fish because it constitutes an important source of income for them. Such discrepancy between the two groups, control versus ASGM sites, is consistent with the findings in other studies in Tanzania and Ghana (Adimado and Baah 2002; Ikingura and Akagi 1996; Voegborlo et al. 2010), which documented a direct relationship between nutrition habits and exposure to $\mathrm{Hg}$.

Such high concentrations of $\mathrm{Hg}$ in the hair of people living in ASGM sites highlight that the previously calculated PWI may underestimate the real $\mathrm{Hg}$ exposure of this group of people or that these populations are exposed to other $\mathrm{Hg}$ sources than the ones from fish. Indeed, mean $\mathrm{Hg}$ concentrations in the hair of people living in ASGM sites equal or exceed the guideline concentrations, even if they eat no more than one fish meal per week. According to Clarkson and Magos (2006), Hg concentrations in hair generally reflect environmental exposures to organic $\mathrm{Hg}$, although they state that about $20 \%$ of $\mathrm{Hg}$ in hair may be derived from inorganic sources. Another explanation about such a difference in $\mathrm{THg}$ content in hair might also be related to direct exposure to gaseous elemental $\mathrm{Hg}$ of people living in mining areas. Indeed, while there is no significant difference in the mean $\mathrm{THg}$ concentrations in hair between men and women in control sites (Fig. 3b), such a difference is significant between men and women living in ASGM sites. At Tinkoto, which is the oldest mining site with a very traditional distribution of daily tasks as a function of gender, mean $\mathrm{THg}$ concentrations in women hair are higher than the ones in men ( $H$ test, $p<0.05-$ Fig. 3b). Women typically perform the apparently less physically demanding manual jobs, including the final stages of gold enrichment, with mixing of $\mathrm{Hg}$ with the gold-bearing grinded rocks for $\mathrm{Hg}$ amalgamation, and amalgam decomposition by heating. By contrast, men are engaged in more specialized, mechanized physically demanding manual jobs, such as digging and bedrock mining, which means that women from this village are much more exposed to vapours of $\mathrm{Hg}^{0}$ during the entire gold mining and ore dressing processes. At Bantako, where hair samples from both men and women have THg concentrations above the US EPA threshold guideline (Fig. 3a), such difference in $\mathrm{Hg}$ concentration in hair is less pronounced between men and women suggesting that both genders are exposed in similar proportions and/or that there is a more equal distribution of tasks during mining and ore processing tasks. In contrast to our study, previous studies did not reveal any relationship of $\mathrm{Hg}$ concentrations in hair and gender (Mortada et al. 2002; Olivero et al. 2002; Agusa et al. 2005).

Finally, we show that amongst people living in ASGM sites, women of childbearing age, pregnant women and children have high $\mathrm{THg}$ contents in hair (Fig. 3b). The comparison of our data set with those of the National Health and Nutrition Examination Survey (NHANES) performed between 1999 and 2000 in the USA (McDowell et al. 2004) shows that measured THg levels in hair of children, pregnant women and women of childbearing age living in ASGM sites were respectively almost five and four times higher than those of the NHANES. Since amongst these susceptible subgroups in ASGM areas children are exposed much earlier in life to other $\mathrm{Hg}$ sources through the placenta of their mothers, and immediately after birth by Hg-contaminated breast milk (Bose-O'Reilly et al. 2010; Xue et al. 2007), careful attention should be applied to this high-risk population.

\section{Conclusions}

This research presents the first assessment of $\mathrm{Hg}$ contamination in fish species and humans from the Kedougou region, eastern Senegal. Amongst the 39 sampled fishes and shellfishes in this study, the majority of the analysed species have $\mathrm{Hg}$ concentrations below international recommended safety. We also evidenced a decrease of $\mathrm{THg}$ concentrations with increasing $\mathrm{Se}: \mathrm{Hg}$ molar ratios suggesting a protection of $\mathrm{Se}$ against $\mathrm{Hg}$ adverse effects. However, people living in ASGM areas, who consume these fishes, revealed high concentrations of $\mathrm{Hg}$ in hair, exceeding the guidelines given by US EPA. Therefore, the major source of $\mathrm{Hg}$ exposure for people living in ASGM sites remains unclear. Indeed, we suggest that these populations are exposed to both organic and elemental $\mathrm{Hg}$ via fish consumption and exposure to $\mathrm{Hg}^{0}$ during amalgam burning, respectively. Our results show that after about 10 years of use of $\mathrm{Hg}$ in the gold ore dressing process, there is a high potential health risk of $\mathrm{Hg}$ toxicity, especially for women of childbearing potential, pregnant women and children living in ASGM sites, whose Hg concentrations in hair are above the toxicity threshold recommended by the US Environmental Protection Agency (Fig. 3b).

For caution, we recommend that piscivorous fish such as $H$. odoe and $S$. intermedius and shellfish with high concentrations of $\mathrm{Hg}$ should not be consumed more than once a week by the local population, particularly for the high-risk groups, including young children under 10 years, pregnant women and frequent fish consumers for whom the World Health Organization threshold guideline was developed. Based on our results on the $\mathrm{Hg}$ concentrations in hair, further studies should consider the use of other bio-indicator such as blood and urine to identify the dominant chemical forms of $\mathrm{Hg}$ and their sources.

Acknowledgments The authors thank the Lombard Foundation (Geneva, Switzerland), Schmidheiny Foundation (Geneva, Switzerland) and 
Sida-UNESCO project 503RAF2000 for financing the study; and the Geological Survey of Senegal (DMG), University Cheikh Anta Diop (Dakar), Dr Diongue and the team of Kedougou hospital and RandGold Company Senegal for their logistic help; and Dr Sarr of the Animal Biology Department at the University Cheikh Anta Diop for fish identification.

\section{References}

Agency for Toxic Substances and Disease Registry (ATSDR) (1999) Toxicological profile for mercury. Atlanta, GA: U.S. Department of Health and Human Services, Public Health Service

Adimado AA, Baah DA (2002) Mercury in human blood, urine, hair, nail, and fish from the Ankobra and Tano River basins in southwestern Ghana. Bull Environ Contam Toxicol 68:339-346

Agusa T, Kunito T, Iwata H, Monirith I, Tana T, Subramanian A, Tanabe S (2005) Mercury contamination in human hair and fish from Cambodia: levels, specific accumulation and risk assessment. Environ Pollut 134:79-86

Airey D (1983) Mercury in human hair due to environment and diet: a review. Environ Health Perspect 52:303-316

Barbosa AC, Jardim W, Dorea JG, Fosberg B, Souza J (2001) Hair mercury speciation as a function of gender, age, and body mass index in inhabitants of the Negro River basin, Amazon, Brazil. Arch. Environ. Contam. Toxicol.40:439-444

Bassot JP (1997) Albitisations dans le Paléoprotérozoïque de l'Est du Sénégal: relations avec les minéralisations ferrifères de la rive gauche de la Falémé. J Afr Earth Sci 25:353-367

Bjornberg KA, Vahter M, Berglund B (2005) Transport of methylmercury and inorganic mercury to the fetus and breast-fed infant. Environ Health Perspect 113:1381-1385

Black FJ, Bokhutlo T, Somoxa A, Maethamako M, Modisaemang O, Kemosedile T, Cobb-Adams C, Mosepele K, Chimbari M (2011) The tropical African mercury anomaly: lower than expected mercury concentrations in fish and human hair. Sci Total Environ 409: $1967-1975$

Bloom N (1992) On the chemical form of mercury in edible fish and marine invertebrate tissue. Can J Fish Aquat Sci 49:1010-1017

Bravo AG, Loizeau JL, Bouchet S, Richard A, Rubin J, Ungureanu V-G, Amouroux D, Dominik J (2010) Mercury human exposure through fish consumption in a reservoir contaminated by a chlor-alkali plant: Babeni reservoir (Romania). Environ Sci Pollut Res 17:1422-1432

Bose-O'Reilly S, Drasch G, Beinhoff C, Tesha A, Drasch K, Roider G et al (2010) Health assessment of artisanal gold miners in Tanzania. Sci Total Environ 408:796-805

Belzile N, Chen Y-W, Gunn JM, Tong J, Alarie Y, Delonchamp T, Lang CY (2006) The effect of selenium on mercury assimilation by freshwater organisms. Can J Fish Aquat Sci 63:1-10 b

Belzile N, Chen YW, Yang DY, Truong HYT, Zhao QX (2009) Selenium bioaccumulation in freshwater organisms and antagonistic effect against mercury assimilation. Environ Bioindic 4:203-21

Burger J, Gochfeld M (2012) Selenium and mercury molar ratios in saltwater fish from New Jersey: individual and species variability complicate use in human health fish consumption advisories. Environ Res 114:12-23

Campbell LM, Norstrom RJ, Hobson KA, Muir DCG, Backus S, Fisk AT (2005) Mercury and other trace elements in a pelagic artic marine food web (Northwater Polynya, Baffin Bay). Sci Total Environ 351352:247-263

Campbell L, Verburg P, Dixon DG, Hecky RE (2008) Mercury biomagnification in the food web of Lake Tanganyika (Tanzania, East Africa). Sci Total Environ 402:184-191
Clarkson TW (2002) The three modern faces of mercury. Environ Health Perspect 110(Suppl 1):11-23

Clarkson TW, Magos L (2006) The toxicology of mercury and its chemical compounds. Crit Rev Toxicol 36:609-62

Chen Y-W, Zhou M-D, Tong J, Belzile N (2005) Application of photochemical reactions of $\mathrm{Se}$ in natural waters by hydride generation atomic fluorescence spectrometry. Anal Chim Acta 545:142-148

Chen Y-W, Belzile N, Gunn JM (2001) Antagonistic effect of selenium on mercury assimilation by fish populations near Sudbury metal smelters? Limnol Oceanogr 46:1814-1818

Donkor AK, Bonzongo JC, Nartey VK, Adotey DK (2006) Mercury in different environmental compartments of the Pra River basin, Ghana. Sci Total Environ 368:164-167

Dos Santos LSN, Müller RCS, Sarkis JES, Alves CN, Brabo ES, Santos EO et al (2000) Evaluation of total mercury concentrations in fish consumed in the municipality of Itaituba, Tapajós River basin, Pará, Brazil. Sci Total Environ 261:1-8

Food and Agriculture Organization (2003) Report of the Expert Consultation on International Fish Trade and Food Security. Casablanca, Morocco, FAO Fisheries Report. No. 708. 213

Francesconi KA, Lenanton RCJ (1992) Mercury contamination in a semienclosed marine embayment: organic and inorganic mercury content of biota and factors influencing mercury levels in fish. Mar Environ Res 33:189-212

Grandjean P, Weihe P, White RF, Debes F, Araki S, Yokoyama K, Murata K, Sorensen N, Dahl R, Jorgensen PJ (1997) Cognitive deficit in 7year-old children with prenatal exposure to methylmercury. Neurotoxicol Teratol 19:417-428

Grandjean P, White RF, Nielsen A, Cleary D, de Oliveira Santos EC (1999) Methylmercury neurotoxicity in Amazonian children: downstream from gold mining. Environ Health Perspect 107:587-591

Grandjean P, Weihe P, White RF (1998) Cognitive performance of children prenatally exposed to "safe" levels of methylmercury. Environ Res 77:165-172

Grieb TM, Driscoll CT, Gloss SP, Schofield CL, Bowie GL, Porcella DB (1990) Factors affecting mercury accumulation in fish in the upper Michigan Peninsula. Environ Toxicol Chem 9:919-930

Gochfeld M, Burger J, Jeitner C, Donio M, Pittfield T (2012) Seasonal, locational and size variations in mercury and selenium levels in striped bass (Morone saxatilis) from New Jersey. Environ Res 112: 8-19

Guédron, S., D. Tisserand, S. Garambois, L. Spadini, F. Molton, B. Bounvilay, L. Charlet and D. A. Polya (2014). Baseline investigation of (methyl)mercury in waters, soils, sediments and key foodstuffs in the Lower Mekong Basin: The rapidly developing city of Vientiane (Lao PDR). Journal of Geochemical Exploration 143:96102

Hammerschmidt C, Wiener JG, Frazier BE, Rada RG (1999) Methylmercury content of eggs in yellow perch related to maternal exposure in four Wisconsin lakes. Environ Sci Technol 33:999 1003

Harris RC, Bodaly RA (1998) Temperature, growth and dietary effects on fish mercury dynamics in two Ontario lakes. Biogeochemistry 40: $175-187$

Ikingura JR, Akagi H (1996) Monitoring of fish and human exposure to mercury due to gold mining in the Lake Victoria goldfields. Tanzania Sci Total Environ 191:59-68

Ikingura J, Akagi H, Mujumba J, Messo C (2006) Environmental assessment of mercury dispersion, transformation and bioavailability in the Lake Victoria goldfields, Tanzania. J Environ Manag 81:167173

Johnson CL (2004) Mercury in the environment: sources, toxicities, and prevention of exposure. Pediatr Ann 33(7):437-442

Kajiwara Y, Yasutake A, Adachi T (1996) Methylmercury transport across the placenta via neutral amino acid carrier. Arch Toxicol 70: 310-314 
Khan M, Wang F (2009) Mercury-selenium compounds and their toxicological significance: toward a molecular understanding of the mercury-selenium antagonism. Environ Toxicol Chem 28:15671577

Kidd K A, Bootsma H A, Hesslein R H, Lyle Lockhart W, Hecky R E (2003) Mercury concentrations in the food web of Lake Malawi, East Africa. Journal of Great Lakes Research 29 Supplement 2:258 266

Kidd KA, Stern G, Lemoalle J (2004) Mercury and other contaminants in fish from Lake Chad. Africa: Bull Environ Contam Toxicol 73:249 256

Kwaansa-Ansah EE, Agorku SE, Nriagu JO (2011) Levels of total mercury in different fish species and sediments from the upper Volta basin at Yeji in Ghana. Bull Environ Contam Toxicol 86: 406-409

Lawrence DM, Treloar PJ, Rankin AH, Harbidge P, Holliday J (2013) The geology and mineralogy of the Loulo mining district, West Africa: evidence for two distinct styles of orogenic gold mineralization. Econ Geol 108:199-227

Lebel J, Mergler D, Branches F, Lucotte M, Amorim M, Larribe F, Dolbec J (1998) Neurotoxic effects of low-level methylmercury contamination in the Amazonian basin. Environ Res Environ Res 79:20-32

Mason RP, Laporte JM, Andres S (2000) Factors controlling the bioaccumulation of mercury, methylmercury, arsenic, selenium, and cadmium by freshwater invertebrates and fish. Arch Environ Contam Toxicol 38:283-297

Matsubara J, Machida K (1985) Significance of elemental analysis of hair as a means of detecting environmental pollution. Environ Res 38: $225-238$

McDowell, M.A.,C.F. Dillon, J. Osterloh, P. M. Bolger, E. Pellizzari, R. Fernando, R. M. de Oca, S.E. Schober, T. Sinks, R.L. Jones and K. R. Mahaffey (2004). Hair Mercury Levels in U.S. Children Women of Childbearing Age: Reference Range Data from NHANES 19992000. EnvironmentalHealth Perspectives 112:1165-1171

Mezghani-Chaari S, Hamza A, Hamza-Chaffai A (2011) Mercury contamination in human hair and some marine species from Sfax coasts of Tunisia: levels and risk assessment. Environ Monit Assess 180: $477-487$

Mortada WI, Sobh MA, El-Defrawy MM, Farahat SE (2002) Reference intervals of cadmium, lead and mercury in blood, urine, hair and nails among residents in Mansoura City, Nile Delta, Egypt. Environ Res 90:104-110

Murata K, Weihe P, Budtz-Jorgensen E (2004) Delayed brainstem auditory evoked potential latencies in 14-year-old children exposed to methylmercury. J Pediatr 144:177-183

Niane B, Moritz R, Guédron S, Ngom PM, Pfeifer HR, Mall I, Poté J (2014) Effect of recent artisanal small-scale gold mining on the contamination of surface river sediment: case of Gambia River, Kedougou region, southeastern Senegal. J Geochem Explor 144: $517-527$

Olivero J, Johnson B, Arguello E (2002) Human exposure to mercury in San Jorje River basin, Columbia (South America). Sci Total Environ 289:41-47
Orihel DM, Paterson MJ, Blanchfield PJ, Bodaly RA, Hintelmann $H$ (2007) Experimental evidence of a linear relationship between inorganic mercury loading and methylmercury accumulation by aquatic biota. Environ Sci Technol 41:49524958

Ouédraogo O, Amyot M (2013) Mercury, arsenic and selenium concentrations in water and fish from sub-Saharan semi-arid freshwater reservoirs (Burkina Faso). Sci Total Environ 444:243-254

Programme d'Appui au Secteur Minier PASMI (2009) Cartographie géologique du Sénégal au 1/500000. Rapport final. Projet 9 ACP SE 009

Peterson SA, Ralston NVC, Whanger PD, Oldfield JE, Mosher WD (2009) Selenium and mercury interactions with emphasis on fish tissue. Environ Bioindicat 4:318-334

Ralston CR, Blackwell JL III, Ralston NVC (2006) Effects of dietary selenium and mercury on house crickets (Acheta domesticus L.): implications of environmental co-exposures. Environ Bioindic 1: 98-109

Ralston NVC, Raymond LJ (2010) Dietary selenium's protective effects against methylmercury toxicity. Toxicology $278: 112-123$

Rashed MN (2001) Monitoring of environmental heavy metals in fish from Nasser Lake. Environ Int 27:27-33

Sakamoto M, Kubota M, Matsumoto S, Nakano A, Akagi H (2002) Declining risk of methylmercury exposure to infants during lactation. Environ Res 90:185-189

Sivaperumal P, Sankar TV, Viswanathan-Nair PG (2007) Heavy metal concentrations in fish, shellfish and fish products from internal markets of India vis-a-vis international standards. Food Chem 102: $612-620$

Sylla M, Ngom PM (1997) Le gisement d'or de Sabodala (Sénégal Oriental): une minéralisation filonienne d'origine hydrothermale remobilisée par une tectonique cisaillante. J Afr Earth Sci 25:183192

Sørmo EG, Ciesielski TM, Øverjordet IB, Lierhagen S, Eggen GS, Berg T et al (2011) Selenium moderates mercury toxicity in free-ranging freshwater fish. Environ Sci Technol 45: $6561-6566$

UNEP/WHO (2008) Guidance for identifying population at risk from mercury exposure UNEP/WHO, Geneva, Switzerland

United States Environmental Protection Agency (1997) Mercury Study Report to Congress Volume IV: An Assessment of Exposure to Mercury in the United States. 293 p. http://www.epa.gov/ttn/oarpg/ t3/reports/volume4.pdf

Voegborlo RB, Matsuyama A, Adimado AA, Akagi H (2010) Head hair total mercury and methylmercury levels in some Ghanaian individuals for the estimation of their exposure to mercury: preliminary studies. Bull Environ Contam Toxicol 84:34-8

World Health Organization (2004) Sixty-first Report of the Joint FAO/ WHO Expert Committee on Food Additive (JEFCA)

Zahir F, Rizwi SJ, Haq SK, Khan RH (2005) Low dose mercury toxicity and human health. Environ Toxicol Pharmacol 20:351-60

Xue F, Holzman C, Rahbar MH, Trosko K, Fischer L (2007) Maternal fish consumption, mercury levels, and risk of preterm delivery. Environ Health Perspect 115:42-47 